Ambiente \& Água - An Interdisciplinary Journal of Applied Science
ISSN 1980-993X - doi:10.4136/1980-993X
www.ambi-agua.net
E-mail: ambi.agua@gmail.com

\title{
Evaluation of the cytotoxic and genotoxic effect of Allium cepa $L$. (Amaryllidaceae) root cells after exposure in water samples of five lakes of Alta Floresta, State of Mato Grosso
}

\author{
ARTICLES doi:10.4136/ambi-agua.2463
}

Received: 29 Aug. 2019; Accepted: 09 Jan. 2020

\author{
Leila Pereira Neves $\operatorname{Ramos}^{1 *}$; Douglas Machado Leite ${ }^{1}$; \\ Weslaine de Almeida Macedo ${ }^{1}$; Cyntia Beatriz Magalhães Farias ${ }^{1}$;

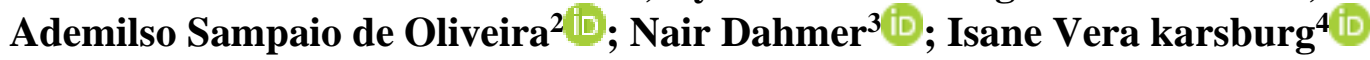 \\ ${ }^{1}$ Programa de Pós-Graduação em Genética e Melhoramento de Plantas. Universidade do Estado de Mato Grosso \\ (UNEMAT), Avenida Perimetral Rogério Silva, s/n, CEP: 78580-000, Alta Floresta, MT, Brazil. \\ E-mail: douglasmachado_95@hotmail.com,weslaine.af@hotmail.com,cyntia_bmf@hotmail.com \\ ${ }^{2}$ Programa em Pós-graduação em Ciências Ambientais. Universidade do Estado de Mato Grosso (UNEMAT), \\ Avenida Santos Dumont, s/n, CEP: 78200-000, Cáceres, MT, Brazil. E-mail: ademilsosampaio@gmail.com \\ ${ }^{3}$ Projeto Escola Verde. Universidade Federal do Vale do São Francisco (UNIVASF), Avenida Antônio Carlos \\ Magalhães, n 510, CEP: 48902-300, Juazeiro, BA, Brazil. E-mail: nairdahmer@ hotmail.com \\ ${ }^{4}$ Faculdade de Ciências Biológicas e Agrárias. Universidade do Estado de Mato Grosso (UNEMAT), \\ Avenida Perimetral Rogério Silva, n 4930, CEP: 78580-000, Alta Floresta, MT, Brazil. \\ E-mail: isane9@gmail.com \\ *Corresponding author. E-mail: leila_pereiraramos@hotmail.com
}

\begin{abstract}
This study evaluated genotoxic and cytotoxic potential of water samples through the analysis of Allium cepa root cells exposed to samples from five urban lakes of Alta Floresta, state of Mato Grosso. The samples were obtained in the dry and rainy periods, October 2014 and April 2015, respectively, at five distinct points. The collection points were as follows: Lake 01, located in MT 206; Lake 02, in Avenida Perimetral Rogério Silva; Lake 03, in Sector C; Lake 04 on Teles Pires Avenue; and Lake 05, in the Cidade Bela District. Bioassays using Allium cepa bulbs were taken from the water at each point, and comparisons were made with the negative and positive controls. The results found the presence of genotoxic and cytotoxic activities on the roots of $A$. сеpa, indicating high potential in cell cycle inhibition. This result may also be caused by the influences of seasonal periods, taking into account that in the rainy season there is a greater transport of cytotoxic substances by rainwater, and in the dry season, a higher concentration of pollutants due to the reduction of water volume, resulting in a greater interaction of the concentrators as well as a greater concentration of the elements found in the water of these lagoons.
\end{abstract}

Keywords: bioassay, genotoxic and cytotoxic potential, seasonal periods.

\section{Avaliação do efeito citotóxico e genotóxico das células radiculares de Allium cepa L. (Amaryllidaceae) após exposição em águas de cinco lagoas de Alta Floresta, Estado do Mato Grosso}

\section{RESUMO}

O presente estudo teve como objetivo avaliar o potencial mutagênico e citotóxico por meio 
da análise das células da raiz de Allium cepa expostas a amostras de águas de cinco lagoas urbanas de Alta Floresta - MT. As amostras foram obtidas nos períodos da seca, outubro de 2014 e chuvoso, abril de 2015, em 5 pontos distintos, sendo os pontos de coletas, a Lagoa 01, situada na MT 206, Lagoa 02, na Avenida Perimetral Rogério Silva, Lagoa 03, no Setor C, Lagoa 04, na Avenida Teles Pires e Lagoa 05, no Bairro Cidade Bela. Bioensaio com bulbos de Allium cepa foram expostos à água de cada ponto, comparando-se com o controle negativo e positivo. Diante dos resultados obtidos foi possível verificar a presença de atividades mutagênico e citotóxico sobre as raízes de A. серa, indicando elevado potencial na inibição do ciclo celular. Esse resultado também pode vir a ser decorrente das influências dos períodos sazonais, levando em consideração, que na estação chuvosa, há maior carreamento de substâncias citotóxicas pela água da chuva e na estação seca, uma maior concentração dos poluentes pela redução do volume de água, conduzindo maior interação dos concentrantes como também, maior concentração dos elementos presente na água dessas lagoas.

Palavras-chave: bioensaio, períodos sazonais, potencial mutagênico e citotóxico.

\section{INTRODUCTION}

Degradation of water resources is a matter of concern, with increasing diagnosis and monitoring of pollution of aquatic environments (Christofoletti, 2008). According to Odum (1998), freshwater ecosystems and estuaries provide the systems that are considered to be the cheapest for effluent disposal. The largest cities in various regions are located near rivers, lakes, lagoons and estuaries, which eventually serve as garbage dumps and sewers; therefore, aquatic contamination by industrial and domestic discharges are of great concern each day for public health (Maria et al., 2003).

Water is an essential resource for sustaining life. However, due to the different pressures applied to water resources, the issue of water availability and quality is one of the problems that is considered fundamental (Gaffney et al., 2015). Household and industrial effluents contain numerous toxic substances that can cause serious damage to genetic material. Aquatic contaminants from landfills in the riparian areas, use of pesticides and fertilizers from agriculture, population growth and the lack of public policies all fuel environmental impacts (Ronconi, 2013).

Allium cepa is considered suitable for analysis of chromosomal damage and disorders in the mitotic cycle induced by toxic agents, a short-term assay with several advantages, such as its low cost, easy handling, chromosomes at adequate conditions for studies on damage or disorder in cell divisions and risk assessments of aneuploidy (Belcavello et al., 2012). A. cepa can detect several classes of contaminants, such as heavy metals, domestic and industrial sewage, landfill extracts and water samples from rivers and lakes, whose solutions include a complex mixture of substances of different compositions. It is efficient and confirms sensitivity and effectiveness (Barbério, 2013).

Biological toxicity and genotoxicity tests are therefore indispensable and recommended for the development of monitoring studies and their purpose is to evaluate the extent of environmental pollution and the reactions of living organisms to the facts proposed (Caritá, 2010). This study evaluated genotoxic and cytotoxic potential of water samples through the analysis of Allium cepa root cells exposed to samples from five urban lakes in Alta Floresta, state of Mato Grosso.

\section{MATERIAL AND METHODS}

The experiment was carried out at the Cytogenetic and Plant Tissue Culture Laboratory of

Rev. Ambient. Água vol. 15 n. 1, e2463 - Taubaté 2020 
UNEMAT, Campus Alta Floresta, state of Mato Grosso, located in Jardim Flamboyant, Alta Floresta, state of Mato Grosso.

The collection sites were named "Lake 01" - located at MT 206; "Lake 02" - on Rogério Silva Avenue; "Lake 03" - at Sector C; "Lake 04" - on Teles Pires Avenue; and "Lake 05" Cidade Bela Neighborhood (Table 1). All lakes belong to the urban area of Alta Floresta, state of Mato Grosso (Table 1 and Figure 1).

In Lake 01, the local population disposes of sewage contaminant materials, remains of dead animals, among other things. From this same lake, the city's water sanitation company collects water to supply the region's population.

In Lake 02, the local population bathes and fishes. The municipal works secretariat draws water from this site during dry periods to wet the dirt streets to mitigate the effects of dust. In Lake 03, some people fish; however, it is used for sewage disposal by the local population.

Lake 04 is located in the central area of the city; just like 03 , the local population uses it to dispose of sewage and household waste, while at the same time some people fish there for food. Lake 05 is located in a more-peripheral area of the city. The local population uses this water for bathing, fishing and garden irrigation. However, the same population disposes of contaminants in this same lake, such as sewage and household waste.

Table 1. Identification of the water collection site in the lakes and GPS data, Alta Floresta - MT.

\begin{tabular}{|c|c|c|}
\hline Treatments & Collection site & Coordinates \\
\hline Lake 1 & Alta Floresta - MT & "South: $09^{\circ} 53^{\prime} 1.23^{\prime \prime}$ "West: $56^{\circ} 8^{\prime} 46.25^{\prime}$ \\
\hline Lake 2 & Alta Floresta - MT & "South: $09^{\circ} 53^{\prime} 42.95^{\prime \prime}$ " West: $56^{\circ} 4^{\prime} 44.69^{\prime}$ \\
\hline Lake 3 & Alta Floresta - MT & "South: $09^{\circ} 52^{\prime} 28.94^{\prime \prime} "$ "West: $56^{\circ} 5^{\prime} 43.20^{\prime \prime}$ \\
\hline Lake 4 & Alta Floresta - MT & "South: $09^{\circ} 52^{\prime} 12.52^{\prime \prime}$ " West: $56^{\circ} 5^{\prime} 38.16^{\prime \prime}$ \\
\hline Lake 5 & Alta Floresta - MT & "South: $09^{\circ} 51^{\prime} 12,13^{\prime}$ "West: 56²'50.29" \\
\hline
\end{tabular}

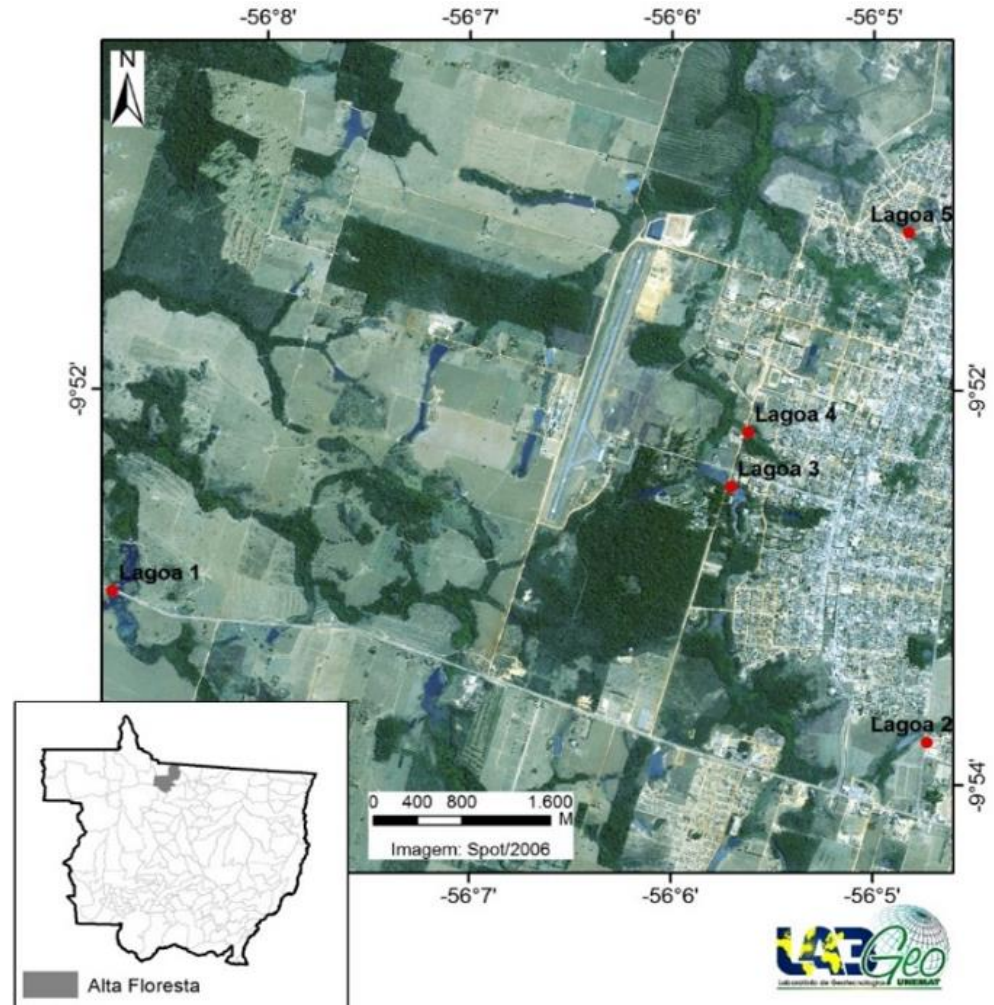

Figure 1. Location of the lakes, environments of water sample collection for the study, Alta Floresta MT. 
Two water sample collections were carried out, in the dry season, October 2014, and in the rainy season, April 2015. Samples were collected from each lake, bank-inland direction, with a maximum distance of $50 \mathrm{~cm}$ from the bank in the first $30 \mathrm{~cm}$ of depth, using a 5 -L polyethylene container for water storage.

The experiment (A. cepa test system) was done soon after the water samples were collected from the lakes. For the tests, seven treatments were used, out of which five were placed in the water sample from the lakes and one in distilled water with dipyrone for the positive control and another only in distilled water for the negative control. The bulbs, 5 repetitions per treatment, were placed in disposable plastic cups $(50 \mathrm{~mL})$ for rooting of the onions. Water was changed every 24 hours. After 72 hours, rootlets of approximately 5-10 mm length were fixed in ethanol-acetic acid $(3: 1)$ and kept in a refrigerator at $4^{\circ} \mathrm{C}$ until use.

For the material digestion process, the root meristems of each sample were washed in distilled water using a plastic pipette on the Petri dish with three water changes, one after the other. Subsequently, the rootlets were dried on absorbent paper and then placed in 5N HCL solution for a period of 15 minutes. At the end of this process, the roots were washed again according to the previous procedure.

For the preparation of the slides, the roots were placed on the slide with the aid of a pair of tweezers and a scalpel, and then the meristematic region was cut, identified by the bleached stains. The rest of the material was discarded, leaving the material with cellular activity on the blade. Following the selection of the material, two drops of $2 \%$ acetic orcein dyes were added, following the maceration and dissociation of the material with the glass rod. The excess of the dye was removed with filter paper for optical microscope visualization and image selection. Ten slides were made per treatment.

Cells were randomly analyzed using the scanning method. A total of 15,000 cells were analyzed, including positive and negative control. The slides were evaluated by observing the cells (interphase, prophase, metaphase, anaphase and telophase) with the aid of an optical microscope at $40 \mathrm{X}$ magnification.

The calculated index values followed the formulas below: $\mathrm{MI}=($ normal cell number $/ 250$ $* 100) ; \mathrm{AP}=($ abnormal cell number $/ 250 * 100) ; \mathrm{PI}=($ number of interphase cells $/ 250 * 100)$; $\mathrm{CTV}=$ Cytotoxicity limit value $=($ positive mitotic index $/$ negative control mitotic index $* 100)$

After counting A. cepa cells, the analysis of variance at 5\% probability was performed and the means were compared by the test of Scott-knott, with the aid of the R software, Version 3.3.2 (R Core Team, 2016).

\section{RESULTS AND DISCUSSION}

Table 2 shows the data on the Mitotic Index (MI) and Anomaly Percentage (AP) of A. cepa obtained from the analysis of the water samples of five lakes collected in Alta Floresta, state of Mato Grosso. The analysis of the respective data showed that when the seasonal periods were compared, L2 followed by L5 and L1 obtained the highest percentages of Mitotic Index (MI) in the dry period, while for the rainy season, L1 had the highest Mitotic Index values of A. cepa cells. The negative control was significant in comparison to the other treatments.

In relation to the Anomaly Percentage $(\mathrm{AP}=)$ of $\mathrm{A}$. cepa (Table 2), when comparing the seasonal periods, the dry period obtained the highest percentage of abnormal cells. The L1, L5 followed by L3 showed the highest abnormal cell indices. In the rainy season, the lakes did not differ statistically and the positive control showed significant statistical data in relation to the other treatments.

According to Tedesco and Laughinghouse IV (2012), Mitotic Index data are used as indicators of adequate cell proliferation. When analyzing the waters of two streams in the state of Paraná, Ferreira et al. (2012), using the bioindicator A. cepa did not find cytotoxicity through mitotic index (MI) analysis.

Rev. Ambient. Água vol. 15 n. 1, e2463 - Taubaté 2020 
Table 2. Mitotic Index (MI), Anomaly Percentage (AP) of Allium cepa obtained in water samples of five lakes in the municipality of Alta Floresta, state of Mato Grosso.

\begin{tabular}{ccccc}
\hline \multirow{2}{*}{ TREATMENT/PERIOD } & \multicolumn{2}{c}{ MI } & \multicolumn{2}{c}{ AP } \\
\cline { 2 - 5 } & Dry & Rainy & Dry & Rainy \\
\hline LAKE 1 & $13.24 \mathrm{bA}$ & $13.4 \mathrm{bA}$ & $7.48 \mathrm{aA}$ & $4.92 \mathrm{aB}$ \\
LAKE 2 & $16.36 \mathrm{~b} \mathrm{~A}$ & $8.64 \mathrm{cB}$ & $5.32 \mathrm{bA}$ & $3.16 \mathrm{aB}$ \\
LAKE 3 & $11.72 \mathrm{cA}$ & $8.44 \mathrm{cB}$ & $7.00 \mathrm{aA}$ & $4.04 \mathrm{aB}$ \\
LAKE 4 & $8.48 \mathrm{dA}$ & $8.76 \mathrm{cA}$ & $5.76 \mathrm{bA}$ & $3.68 \mathrm{aB}$ \\
LAKE 5 & $15.08 \mathrm{bA}$ & $9.04 \mathrm{cB}$ & $7.48 \mathrm{aA}$ & $4.04 \mathrm{aB}$ \\
POSITIVE CONTROL & $11.8 \mathrm{c}$ & $11.8 \mathrm{~b}$ & $3.93 \mathrm{c}$ & $3.93 \mathrm{a}$ \\
NEGATIVE CONTROL & $23.08 \mathrm{a}$ & $23.08 \mathrm{a}$ & $0 \mathrm{~d}$ & $0 \mathrm{~b}$ \\
\hline \multicolumn{3}{c}{27,09} & \multicolumn{2}{c}{33,47} \\
\hline
\end{tabular}

Means followed by the same lower-case letter in the column and upper-case letter in the line are not different from each other by the test of Scott-knott at $5 \%$ probability.

In a study developed in the Paraíba do Sul River (SP), Oliveira et al. (2011) found that the mitotic index (MI) did not differ significantly from the control group.

Differences in toxicity between collection points may be related to water volume and may influence between seasonal periods and concentrations of toxic substances (Scalon, 2009; Oliveira et al., 2012). This was observed in this study for all lakes in the dry season, where the values of the mitotic index and percentage of anomalies were higher than the rainy season.

In a study using A. cepa bulbs in Rio dos Sinos (Rio Grande do Sul - RS), Oliveira et al. (2012) obtained results with occurrence of cytotoxicity in the dry season. On the other hand, for the rainy season period, they did not find any significant results; these results corroborate those found in this paper. Galvão et al. (2015) reported in one of their works that A. cepa is considered an efficient bioindicator in this kind of analysis

Cuchiara et al. (2012), in an analysis of the waters of Arroio Padre Doutor (RS) in the rainy season using bioindicator $A$. cepa, did not obtain any results of interference with root growth. These results may be caused by the greater fluviometric volume in this period.

For the data obtained in the rainy season analysis, Bianchi et al. (2011), in tests carried out with water samples from the Monjolinho River, were not statistically different when compared to the negative control data; however, it differed from the dry period.

Faria et al. (2017), in a study of the toxicity potential in water samples of the Jaru River in the State of Rondônia during the dry season, August 2011, and rainy season, February 2012, using A. cepa cells, obtained results where the A. cepa test showed cytotoxicity in relation to root growth only for the dry season. Nevertheless, this fact was not observed for the Mitotic Index with significance in any of the analyzed periods.

Table 3 shows the Interphase Percentage (IP) numbers and the A. cepa Cytotoxicity Limit Value (VLC). The analysis of these data shows that L4 obtained the highest interphase cell indices as the positive control obtained percentages that are considered significant when compared to the other treatments of the experiment. For the cytotoxicity threshold values (CTV), the treatments of the dry period reduced the Mitotic Index, impairing cell division. Therefore, it is possible to observe by the cytotoxicity threshold value that the treatments of the dry period have greater cytotoxic effect than the treatments of the rainy season. This may have occurred due to the dissociation of some substances in the lake water, and in relation to the water volume of each lake in each period. Statistically, the negative control showed significant results in relation to the positive control and the other treatments.

Mitosis takes only a small proportion of the cell cycle, approximately 5 to $10 \%$. The 
remaining time is for the interphase, composed of stages G1, S and G2. DNA is replicated during the $\mathrm{S}$ phase. Chromosomes cannot be seen during interphase because they are in a distended and intertwined state (Griffiths et al., 2011).

Table 3. Percentage of Interphase (PI) and Cytotoxicity Threshold Value (CTV) of Allium cepa obtained from the water samples of five lakes in the municipality of Alta Floresta, state of Mato Grosso.

\begin{tabular}{ccccc}
\hline \multirow{2}{*}{ TREATMENTS/PERIOD } & \multicolumn{2}{c}{ PI } & \multicolumn{2}{c}{ CTV } \\
\cline { 2 - 5 } & Dry & Rainy & Dry & Rainy \\
\hline LAKE 1 & $79.28 \mathrm{bA}$ & $81.68 \mathrm{bA}$ & $57.36 \mathrm{bA}$ & $58.05 \mathrm{bA}$ \\
LAKE 2 & $78.32 \mathrm{bB}$ & $88.20 \mathrm{aA}$ & $70.88 \mathrm{bA}$ & $37.43 \mathrm{cB}$ \\
LAKE 3 & $81.28 \mathrm{bB}$ & $87.52 \mathrm{aA}$ & $50.78 \mathrm{cA}$ & $36.56 \mathrm{cB}$ \\
LAKE 4 & $85.76 \mathrm{aA}$ & $88.16 \mathrm{aA}$ & $36.74 \mathrm{dA}$ & $37.95 \mathrm{cA}$ \\
LAKE 5 & $77.44 \mathrm{cB}$ & $87.32 \mathrm{aA}$ & $65.33 \mathrm{bA}$ & $39.16 \mathrm{cB}$ \\
POSITIVE CONTROL & $84.26 \mathrm{a}$ & $84.26 \mathrm{a}$ & $51.12 \mathrm{c}$ & $51.12 \mathrm{~b}$ \\
NEGATIVE CONTROL & $76.92 \mathrm{~b}$ & $76.92 \mathrm{c}$ & $99.99 \mathrm{a}$ & $99.99 \mathrm{a}$ \\
\hline \multicolumn{3}{c}{4.98} & \multicolumn{3}{c}{27,09} \\
\hline
\end{tabular}

Means followed by the same lowercase letter in the column and uppercase letter in the row do not differ statistically by the test of Scott-knott at 5\% probability.

According to Fachinetto et al. (2007), the occurrence of an interphase cell index act may be associated with the antiproliferative consequence of mitotic cells. Souza et al. (2013) report that the antiproliferative effect can be observed through the inhibition of mitosis, or if there is a high number of interphase cells.

Oliveira et al. (2013) report that a reduction in the CTV of less than $22 \%$ of the negative control value can cause lethal effects, and reductions below 50\% usually cause sublethal effects.

While studying the antiproliferative effect of Ilex paráguariensis on the cell cycle of $A$. cepa bioindicator, Conceição (2010) found that the treatments using infusions (chimarrão) had VLC lower than $50 \%$, and sublethal effects; however, for treatments using cold water (tereré), the Mitotic Index was not reduced.

Based on the cells observed in the study, different types of chromosomal anomalies were found: micronucleus binucleate interphase, three-block metaphase, isolated chromosome metaphase, isolated chromosome anaphase, delayed displacement chromatin, delayed telophase in organization of the chromatids in its block, final telophase with presence of micronucleus, metaphases with chromosomal adhesion, metaphases and anaphases with chromosomal bridges. Based on the analyses, it is found that genotoxic action occurred, as abnormal cells were found during cell division processes, with genotoxic effects. The results obtained for the mitotic index from the study using the $A$. серa test system were considered satisfactory and indicative of genotoxic potential on A. cepa cells (Figure 2).

Souza et al. (2012) report in one of their works that the genotoxic potential is evident because of the presence of chromosomal anomalies analyzed at all collection points, in which alteration in cells in metaphase with $\mathrm{C}$-metaphase, in anaphases with bridges, loss and multipolarity, and binucleated cells were the most observed anomalies in the trials, besides chromosome breaks and losses. Therefore, water treatment with concentrating agents causes genotoxicity in the meristematic cells of A. cepa.

Leme et al. (2009), report that chromosomal abnormalities in A. cepa can be found in the stages of mitosis (prophase, metaphase, anaphase and telophase). The micronuclei originate from acentric chromosomal fragments resulting from mitotic spindle dysfunctions and may appear more than once in each cell (Balieiro et al., 2010). 
Marcano et al. (2004), point out that chromosomal bridges may have occurrences with consequences of a junction and then a failure in the separation of chromosomes in anaphase, and it can also be attributable to an unequal translocation or inversion of chromosome segments.

According to Esteves (1998), in flooding environments, lakes or very shallow lakes, there may be a greater interaction of the elements found in the sediment with the water column, and this may occur seasonally.

However, it is observed that a higher rate of abnormal cells occurred over the dry season, because in the dry season, there may be a greater interaction of concentrates in the waters of these lagoons, resulting in a concentration of residues in the water.

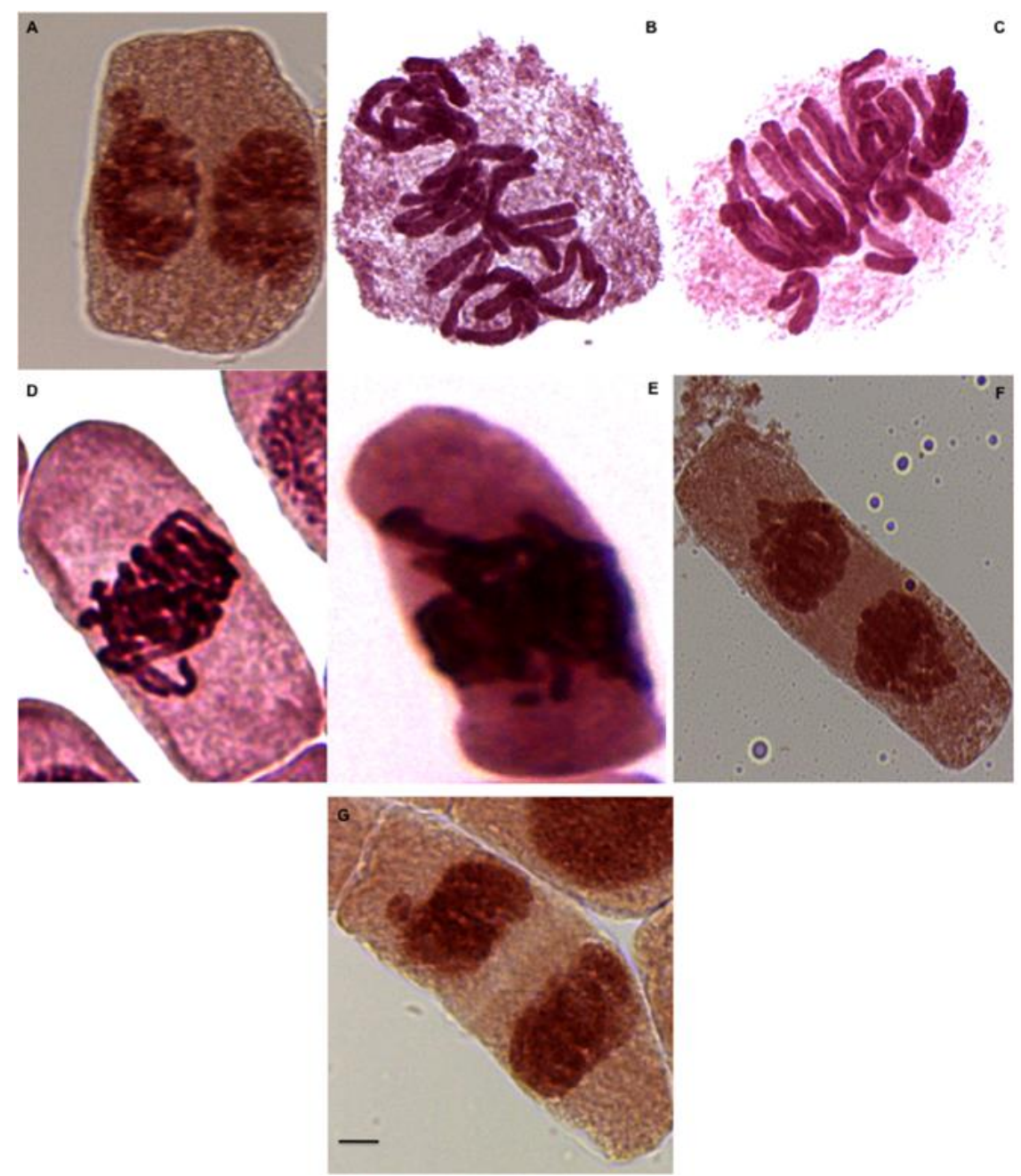

Figure 2. Allium cepa cell from cell division, obtained from different exposure treatments in water samples from lakes located in Alta Floresta - MT. (a) micronucleus binucleate interphase; b) Metaphase with formation of three blocks; c) Metaphase with isolated chromosome; d) Anaphase with isolated chromosome; e) Anaphase with isolated chromosome and delayed displacement chromatin; f) Telophase with delayed organization of the chromatids in each block; g) Final telophase with presence of micronucleus, $\mathrm{Bar}=10 \mu \mathrm{m}$.

\section{CONCLUSIONS}

Based on the results of the study, it was possible to observe the presence of genotoxic and cytotoxic activities on the roots of Allium cepa, indicating high potential in cell cycle inhibition. This result may also be caused by the influences of seasonal periods, taking into account that a 
higher transport of cytotoxic substances by rainwater occurs in the rainy season, and in the dry season, there is a higher concentration of pollutants due to the reduction of water volume, leading to greater interaction of the concentrators as well as greater concentration of the elements found in the waters of these lakes.

\section{REFERENCES}

BALIEIRO, F. P.; BARBOSA, S.; FREITAS, N. C.; RIBEIRO, L. O.; BEIJO, L. A.; SANTOS, B. R. Influência de extratos foliares de bartimão sobre a germinação e ciclo celular de Allium cepa. In: CONGRESSO DE PÓS-GRADUAÇÃO DA UFLA, 19., 2010, Lavras. Anais[...] Lavras: APG, 2010.

BARBÉRIO, A. Bioassays with plants in the monitoring of water quality. Water treatment, p. 317-334, 2013. https://dx.doi.org/10.5772/50546

BElCAVEllo, L.; CUNHA, M. R. H.; ANDRADE, M. A.; BATITUCCI, M. D. C. P. Citotoxicidade e danos ao DNA induzidos pelo extrato de Zornia diphylla, uma planta medicinal. Natureza on line, v. 10, n. 3; p. 140-145, 2012.

BIANCHI, J.; ESPINDOLA, E. L. G.; MARIN-MORALES, M. A. Genotoxicity and mutagenicity of water samples from the Monjolinho River (Brazil) after receiving untreated effluents. Ecotoxicology and Environmental Safety, v. 74; p. 826-833, 2011. https://dx.doi.org/10.1016/j.ecoenv.2010.11.006

CARITÁ, R. Avaliação do potencial genotóxico e mutagênico de amostras de águas de recursos hídricos que recebem efluentes urbanos e industriais do pólo ceramista da cidade de Santa Gertrudes - SP. 2010. Dissertação (mestrado) - Universidade Estadual Paulista, Instituto de Biociências de Rio Claro, Rio Claro, 2010.

CONCEIÇÃO, T. S. Efeito antiproliferativo, mutagênico e antineoplásico de produtos comerciais da erva mate (Ilex paraguariensis). 2010. 72p. Dissertação (Mestrado em Saúde e Desenvolvimento da Região Centro-Oeste) - Universidade Federal do Mato Grosso do Sul, Campo Grande, 2010.

CUCHIARA, C. C.; BORGES, C. S.; BOBROWSKI, V. L. Sistema teste de Allium cepa como bioindicador da citogenotoxicidade de cursos d'água. Revista Tecnologia \& Ciência Agropecuária; v. 6, n. 1; p. 33-38, 2012.

CHRISTOFOLETTI, C. A. Avaliação dos potenciais citotóxico, genotóxico e mutagênico das águas de um ambiente lêntico, por meio dos sistemas-teste de Allium cepa e Areochromis niloticus. 2008. Dissertação (mestrado) - Universidade Estadual Paulista, Instituto de Biociências de Rio Claro, Rio Claro, 2008.

ESTEVES, F. A. Fundamentos de Limnologia. 2. ed. Rio de Janeiro: Interciência, 1998. 602 p.

FARIA, M. L. C. de; COSTA, F. M. da; SILVA, F. C. da; BOSSO, R. M. do V. Potencial de citotoxicidade e mutagenicidade das águas do rio Jaru, estado de Rondônia, em células de Allium cepa. Gaia Scientia, v. 11, n. 2, 2017. http://dx.doi.org/10.22478/ufpb.1981$1268.2017 \mathrm{v} 11 \mathrm{n} 2.29160$

FACHINETTO, J. M.; BAGATINI, M. D.; DURIGON, J.; SILVA, A. C. F.; TEDESCO, S. B. Efeito antiproliferativo das infusões de Achyrocline satureioides DC (Asteraceae) sobre o ciclo celular de Allium cepa. Revista Brasileira de Farmacologia, v. 17, p. 49-54, 2007. http://dx.doi.org/10.1590/S0102-695X2007000100011 
FERREIRA, C. F.; FRUEH, A. B.; DUSMAN, E.; HECK M. C.; VICENTINI V. E. P. Avaliação da citotoxicidade das águas dos ribeirões Varginha (Califórnia-PR) e Tabatinga (Mandaguari-PR), em Allium cepa L. SaBios: Revista de Saúde e Biologia, v. 7, n. 2, p. 46-54, 2012.

GAlVÃO, M.; MIRANDA, D. P.; COSTA, G. M.; SIlVA, A. B.; KARSBURG. I. V. Potencial Mutagênico em águas coletadas em diferentes pontos no Perímetro Urbano no município de Alta Floresta - MT através o Teste Allium (Allium Cepa). Enciclopédia Biosfera, Centro Científico Conhecer, v. 11, n. 21; p. 2373, 2015.

GRIFFITHS, A.; WESSLER, S. R.; LEWONTIN, R. C.; CARROLL, S. B. Introdução à Genética. 9. ed. Rio de Janeiro: Guanabara Koogan, 2011. 712p.

GAFFNEY, V.; ALMEIDA, C. M. M.; RODRIGUES, A.; FERREIRA, E.; BENOLIEL, M. J.; CARDOSO, V. V. Occurrence of pharmaceuticals in a water supply system and related human health risk assessment. Water Research, v. 72, p. 199-208, 2015. https://doi.org/10.1016/j.watres.2014.10.027

LEME, D. M.; MARIN-MORALES, M. A. Allium cepa test in environmental monitoring: a review on this application. Mutation Research, v. 682, n. 1, p. 71-81, 2009. https://doi.org/10.1016/j.mrrev.2009.06.002

MARCANO, L.; CARRUYO, I.; CAMPO, A. D. Montiel, X. Cytotoxicity and mode of action of maleic hydrazide in root tips of Allium cepa L. Environmental Research. v. 94, n. 2, p. 221-226, 2004. https://dx.doi.org/10.1016/S0013-9351 (03)00121-X

MARIA, V. L.; CORREIA, A. C.; SANTOS, M. A. Genotoxic and biochemical responses in caged e el (Anguilla Anguilla L.) after short-term exposure to harbour waters. Environment International, v. 29, n. 7, p. 923-929, 2003. https://dx.doi.org/10.1016/S0160-4120 (03)00057-6

ODUM, E. P. Breve descrição dos principais tipos de Ecossistema Natural na Biosfera. Rio de Janeiro: Guanabara Koogan, 1998. p. 367-369.

OLIVEIRA, A. M.; LEMOS, R. P. L.; CONSERVA, L. M. $\beta$-Carboline alkaloids from Psychotria barbiflora DC. (Rubiaceae). Biochemical Systematics and Ecology, v. 50, p. 339-341, 2013. https://dx.doi.org/10.1016/j.bse.2013.04.015

OLIVEIRA, J. P. W.; SANTOS, R. N. dos; PIBERNAT, C. C.; BOEIRA, J. M. Genotoxicidade e análises físico-químicas das águas do rio dos Sinos (RS) usando Allium cepa e Eichhornia crassipes como bioindicadores. Biochemistry and Biotechnology Reports, v. 1, n. 1, p. 15-22, 2012. http://dx.doi.org/10.5433/2316-5200.2012v1n1p15

OLIVEIRA, L. M. de; VOLTOLINI, J. C.; BARBÉRIO, A. Potencial mutagênico dos poluentes na água do rio Paraíba do Sul em Tremembé, SP, Brasil, utilizando o teste Allium cepa. Revista Ambiente \& Água, v. 6, n. 1, p. 90-103, 2011. https://dx.doi.org/10.4136/ambi-agua.176

R CORE TEAM. R: A language and environment for statistical computing. Vienna, 2016.

RONCONI, A. T. Caracterização do sedimento de fundo, Avaliação da Qualidade da Água e medição da Vazão do Arroio Ouro Verde. Revista Cultivando o Saber, p. 121-127, 2013.

SCALON, M. C. S. Avaliação dos efeitos genotóxicos da água do rio dos Sinos sobre peixes e vegetais. 2009. Dissertação (Mestrado em Qualidade Ambiental) - Centro Universitário Feevale, Novo Hamburgo, 2009. 
SOUZA, R. K. D.; MENDONÇA, A. C. A. M.; SILVA, M. A. P. Aspectos etnobotânicos, fitoquímicos e farmacológicos de espécies de Rubiaceae no Brasil. Revista Cubana de Plantas Medicinales, v. 18, n. 1, p. 140-156, 2013.

SOUZA, C. P. de; FERREIRA, M. A. M. M.; GUEDES, T. de A. Avaliação do Potencial Genotóxico e Mutagênico das águas da lagoa maior e dos córregos da Onça e do Pinto (Três Lagoas - MS), em Células Meristemáticas de Allium cepa, 2012.

TEDESCO, S. B.; LAUGHINGHOUSE IV, H. D. Bioindicator of Genotoxicity: The Allium cepa Test. In: SRIVASTAVA, J. K. Environmental Contamination. Rijeka: InTech, 2012. p. 137-156. https://dx.doi.org/10.5772/31371 